\title{
Evolution of longitudinally extensive transverse myelitis in an aquaporin-4 IgG-positive patient
}

\section{Figure Sequential brainstem/spinal cord MRIs}

\section{Days after vomiting}

onset: $\quad+1$

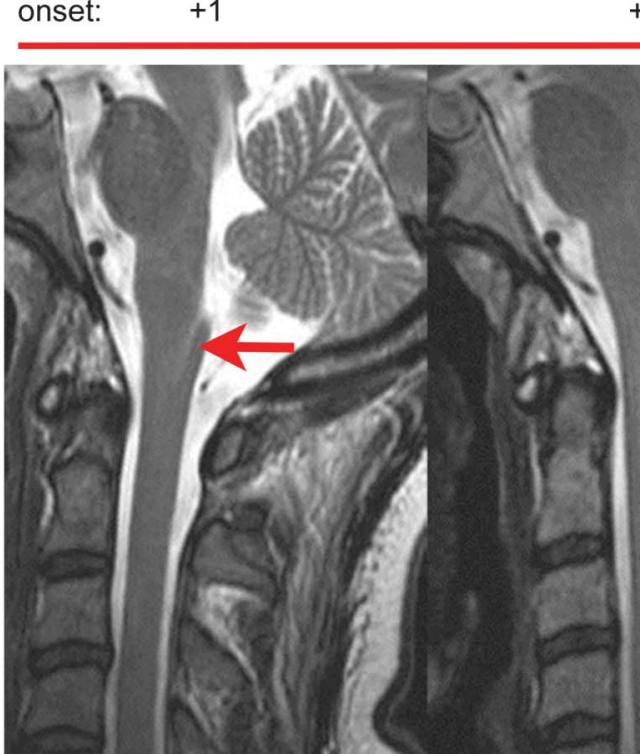

$+2$ $+12$

Signal abnormality starting in the fourth ventricle floor (area postrema; day 1) evolves over the next 10 days to upper cervical transverse myelitis. The aquaporin-4-rich area postrema, which is the vomiting center of the medulla oblongata, lacks a blood-brain barrier. Sagittal images, T2-weighted (without contrast).

A 36-year-old woman presented with hemiplegia and loss of pain and temperature sensation 1 day after the subacute onset of intractable vomiting. Paresthesia followed. She was tetraplegic at day 12. Initial MRI revealed a lesion in the medulla oblongata, involving primarily the area postrema (figure). The lesion progressively extended into the upper cervical cord. Forebrain MRI was normal. CSF contained 11 leukocytes $/ \mathrm{mm}^{3}$. Brainstem tumor and multiple sclerosis were early diagnostic considerations. Aquaporin- 4 immunoglobulin (Ig)G was detected in serum. This case supports the concept that fenestrated capillaries in the area postrema are an important initial CNS entry site for pathogenic neuromyelitis optica- $\operatorname{IgG}$ in neuromyelitis optica spectrum disorders. ${ }^{1,2}$

Nasrin Asgari, MD, PhD, Hanne Pernille Bro Skejoe, MD, Vanda A. Lennon, MD, PhD

From the Department of Neurology (N.A.), Vejle Hospital, Denmark; Institutes of Molecular Medicine and Regional Research (N.A.), University of Southern Denmark, Odense; Radiology Clinic (H.P.B.S.), Aleris-Hamlet Hospital, Copenhagen, Denmark; and Mayo Clinic (V.A.L.), Rochester MN.

Author contributions: N. Asgari: study concept and design, acquisition and interpretation of data, writing of draft manuscript. H.P.B. Skejoe: MRI reevaluation and manuscript revision. V.A. Lennon: discussion of case and immunopathogenic implications and revision of manuscript.

Study funding: No targeted funding reported.

Disclosure: N. Asgari and H.P.B. Skejoe report no disclosures. Mayo Clinic holds a patent relating to aquaporin-4 as a target of pathogenic autoantibodies in neuromyelitis optica and related disorders. V.A. Lennon has received royalties exceeding the federal threshold for significant financial interest from the licensing of this technology and has rights to receive future royalties. In addition, V.A. Lennon is a named inventor on 2 patent applications filed by Mayo Foundation for Medical Education and Research relating to functional assays for detecting aquaporin-4 $\operatorname{IgG}$ and applications to cancer. She receives no revenue from the sale of serologic tests performed by Mayo Medical Laboratories. Go to Neurology.org for full disclosures. 
1. Broadwell RD, Sofroniew MV. Serum proteins bypass the blood-brain fluid barriers for extracellular entry to the central nervous system. Exp Neurol 1993;120:245-263.

2. Apiwattanakul M, Popescu BF, Matiello M, et al. Intractable vomiting as the initial presentation of neuromyelitis optica. Ann Neurol 2010;68:757-761.

\section{NeuroImages Are Free at www.neurology.org!}

All Neurology ${ }^{\circledR}$ NeuroImages can now be freely accessed on the Neurology Web site. See them at www.neurology.org, where you can also sign up for journal email alerts and check out other online features, including the Resident \& Fellow section, Neurology: Clinical Practice, and the weekly Neurology Podcasts. 


\section{Neurology}

\section{Evolution of longitudinally extensive transverse myelitis in an aquaporin-4 IgG-positive patient}

Nasrin Asgari, Hanne Pernille Bro Skejoe and Vanda A. Lennon

Neurology 2013;81;95-96

DOI 10.1212/WNL.0b013e318297ef07

\section{This information is current as of July 1, 2013}

\section{Updated Information \& Services}

References

Subspecialty Collections

Permissions \& Licensing

Reprints including high resolution figures, can be found at: http://n.neurology.org/content/81/1/95.full

This article cites 2 articles, 0 of which you can access for free at: http://n.neurology.org/content/81/1/95.full\#ref-list-1

This article, along with others on similar topics, appears in the following collection(s):

Autoimmune diseases

http://n.neurology.org/cgi/collection/autoimmune_diseases Devic's syndrome

http://n.neurology.org/cgi/collection/devics_syndrome

MRI

http://n.neurology.org/cgi/collection/mri

Transverse myelitis

http://n.neurology.org/cgi/collection/transverse_myelitis

Information about reproducing this article in parts (figures,tables) or in its entirety can be found online at:

http://www.neurology.org/about/about_the_journal\#permissions

Information about ordering reprints can be found online:

http://n.neurology.org/subscribers/advertise

Neurology ${ }^{\circledR}$ is the official journal of the American Academy of Neurology. Published continuously since 1951, it is now a weekly with 48 issues per year. Copyright @ 2013 American Academy of Neurology. All rights reserved. Print ISSN: 0028-3878. Online ISSN: 1526-632X.

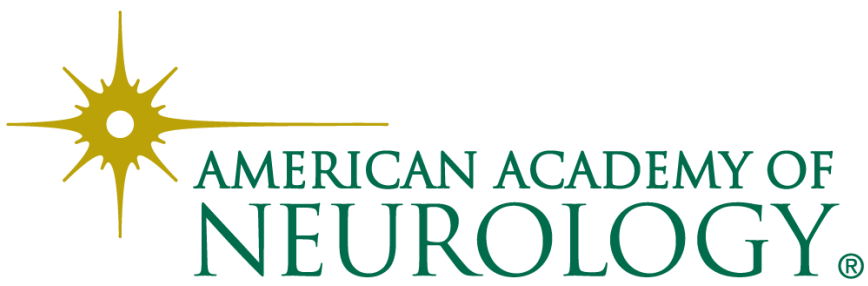

